\title{
Foreword
}

\section{Richard Whish}

This book is a superb - and very timely - addition to the literature on competition law and policy. The application of competition law in practice has become highly sophisticated and some cases are of immense complexity: the FRAND licensing of standard-essential patents comes to mind as an obvious example of this. Competition authorities and courts that apply competition law obviously seek to find the 'right' answer in any particular case: a false positive - attaching guilt to behaviour that in fact is pro-competitive - is just as harmful as a false negative permitting behaviour that in fact is anti-competitive. It is inevitable that errors will be made, and we all endeavour to learn from those that do occur. One of the great challenges for competition law is to devise ways for the insights and discipline of economics to be absorbed into the competition legal order: the law needs to provide clarity and certainty to its relevant stakeholders, who include not only businesses and complainants and their legal and economic advisers but also the officials of competition authorities, decision-makers, judges and civic society generally. I have always described competition law as the economic analysis of markets within a legal process, and I have been delighted, over many years, to watch lawyers and economists in the EU move from mutual suspicion - even hostility - to a much more consensual relationship in which each respects the expertise of the other and works jointly to try to reach the correct outcome in any given case. Of course there can and will still be friction, but we should not underestimate the huge changes that have taken place: today many economists take courses in competition law and many competition lawyers study industrial economics.

I began to study competition law in 1977: Continental Can and Commercial Solvents, both decided in 1973, were still 'new'; United Brands (1978) and Hoffmann-la Roche (1979) had yet to be decided. Discussion in the literature of these cases was mainly in the hands of lawyers (practising or academic); officials of the Commission would sometimes add to the debate in a personal capacity, but they were rarely economists. In the pre-internet era it was not easy for lawyers to access 
material on economics, and economists in the EU were not particularly interested in competition law cases. In due course the position began to change, in particular when the EU Merger Regulation came into force in 1990: the European Commission would now have to conduct an 'economic analysis of markets within a legal process' in three hundred or more cases each year, rather than in a mere handful as was the case under the antitrust rules. It has always seemed to me that it was the Merger Regulation that profoundly changed competition law in practice, leading to the demand - largely now met - for a more 'effects-based' approach to the application of the competition rules.

An important feature of the Continental Can judgment was that the Court held that the Commission could not reach a conclusion that a dominant position had been abused without first defining the relevant market in which the dominant position was held. From that relatively small seed the mighty tree of market definition grew, to the point where today we need to define markets for a myriad of reasons: not just when determining if an undertaking is dominant, but also for example when working out whether a merger will significantly impede (or substantially lessen) competition, whether an agreement has the effect of restricting competition, or whether an agreement is de minimis or block exempted. This is not an exhaustive list. So one possible answer to Professor Louis Kaplow's famous question in the Harvard Law Review - 'Why (ever) define markets?' - could be that, at least as a matter of EU law, it is a legal requirement to do so. Of course as an answer this is not good enough, because it simply begs the question: 'Well, in that case, should the law be changed?'. Indeed, there are plenty of people today who think that we could dispose of market definition altogether, and instead develop (or develop further) tools that enable us to identify market power, or increases of market power, without pausing on the way to define a relevant market which is an artificial legal construct and which may be incorrect anyway.

The role of market definition is an important, and very topical, debate. I chaired a conference on the subject in Stockholm in 2017, hosted by the Swedish Competition Authority in its excellent 'Pros and Cons' series: the event can be accessed on the Authority's website. In the course of the day more 'Cons' were identified than 'Pros', and yet there was a consensus at the end of it that nevertheless it was worth retaining market definition as an important part of competition analysis, albeit with some major caveats.

Professor Ferro's book makes an invaluable contribution to the debate on market definition. One point that the author makes is that legal scholarship has been thin on this topic: just as it has often seemed that 
courts of judicial review tend to defer to the 'margin of appreciation' of competition authorities in their definition of markets, so also the legal community has perhaps tended to defer unduly to the economics literature on this subject. However, as Professor Ferro points out, market definition is a legal construct, and it performs important roles in the competition legal order. We all need to understand as much as we can about the role of market definition, its legal meaning and how it is conducted in practice.

To my mind, market definition has a useful role to play in the economic analysis of markets, as long as we recognise its limitations as well as its strengths. The main limitation is that market definition does not tell us whether a firm or firms have or will have market power; but at least it can assist us when trying to address that question. The Commission's 1997 Notice on the Relevant Market specifically says that market definition is not an end in itself; rather it is a means to an end. The former Commissioner for Competition, Professor Mario Monti, put this point well when he said that market definition is 'a cornerstone of competition policy, but not the entire building. Market definition is a tool for the competition assessment, not a substitute for it'. In the UK the Competition and Markets Authority speaks of market definition as a 'framework of reference' for the analysis of mergers, but of course market share figures within a market can tell us nothing about competitive constraints from outside it (for example potential competition and buyer power). The 1997 Notice imported the SSNIP test from the US: competition lawyers in the EU now had to familiarise themselves with the idea of the 'hypothetical monopolist' and to understand how pricing data could be used to help them to define the relevant market. In practice, however, it soon became clear that in most cases it was NOT pricing data that were used: indeed decisions rarely referred to the SSNIP test at all. In other words, the Notice was really about providing a conceptual framework within which to think about markets rather than a particular methodology for doing so. The Notice is helpful if it is not expected to do too much. The SSNIP test as a concept becomes particularly difficult to apply in practice as one moves away from simple industrial markets to the more complex markets of today - platforms, two-sided and multisided markets, 'free' products etc. To put the point another way, market definition is useful when it is simple, but not in the more complex situations with which competition authorities have to grapple today.

For the foreseeable future market definition will remain with us, and cases will continue to be litigated in the European Courts. I think that it is incontrovertible that the Courts historically have been deferential to the Commission's margin of appreciation in this area. After Continental Can 
in 1973, which established the need for the Commission to define the relevant market, the Commission has lost only three cases under the (non-state aid) competition rules in the subsequent 45 years. The first was a small point in the Tetra Laval judgment of 2002 in relation to the Tetra Laval/Sidel merger; the second occurred in relation to Swiss watches and spare parts in the CEAHR judgment of 2010 dealing with the rejection of a complaint by the Commission. However the third case, Servier in December 2018, seems to me to be a significant event, not only in relation to market definition in particular but to judicial review in Luxembourg more generally. It is trite to say that the Commission has formidable powers under the competition rules, and it has been dealing with many cases of the utmost complexity and controversy (both in terms of economics and politics). The administrative model of enforcing competition law in the EU can really be justified only if the Luxembourg Courts, and the General Court in particular, make use of the powers available to them to ensure that the Commission operates within the legal framework of competition law, of which market definition forms part. The judgment of the European Court of Human Rights in Menarini Diagnostics in 2011 triggered a much-needed debate within the EU about the need for effective judicial review, and there seems little doubt that the General Court in recent years has taken note of this debate and has been responding accordingly. The tension around market definition would surely be diminished, at least to some extent, if a real possibility exists to challenge the Commission's conclusions in Luxembourg. Market definition will be a key part of the appeals to the General Court in both Google Shopping and Google Android.

Professor Ferro's book makes an invaluable contribution to this important and fascinating debate and will quickly establish itself as a seminal text on the subject.

Richard Whish, QC (Hon), Emeritus Professor of Law

King's College London

Marshfield, March 2019 